\title{
Vitamin A content of human liver from autopsies in New Zealand
}

\author{
By BARBARA M. SMITH AND EILEEN M. MALTHUS* \\ Nutrition Research Department, Medical Research Council of New Zealand, \\ University of Otago Medical School, Dunedin, New Zealand \\ (Received 12 September 1961-Revised I $_{5}$ fanuary 1962)
}

Experiments on rats and other animals by Sherman \& Boynton (1925), Kerppola (1930) and Moore (r93I) have established that the body's main stores of vitamin A are in the liver; thus the hepatic concentration provides a convenient index of the body's vitamin A status.

Many studies have been carried out to determine a value for the vitamin A reserve that may be considered typical for the normal human being, and also to discover whether in any diseases other than deficiency diseases low vitamin A reserves occur. No values have been recorded for New Zealanders, and it was thought of interest to study the reserves in inhabitants of a primary producing country where butter consumption is high and pharmaceutical prescriptions free.

\section{EXPERIMENTAL}

Vitamin A was determined by a modification of the U.S. Pharmacopoeia, XIV (I950) method.

Autopsy samples of about $5 \mathrm{~g}$ were weighed into screw-capped bottles and covered with $5 \%(\mathrm{w} / \mathrm{w})$ aqueous $\mathrm{KOH}$ (Moore, 1937). Specimens from centres other than Dunedin were up to 2 days in airmail transit, but control experiments showed that no loss was likely under these conditions. For analysis, the specimen was transferred to a flask with low u.v. transmission to which were added $30 \mathrm{ml} 95 \%$ ethanol containing $30 \mathrm{mg}$ pyrogallol and $2 \mathrm{ml} 50 \%(\mathrm{w} / \mathrm{w})$ aqueous $\mathrm{KOH}$. The mixture was refluxed on a water-bath for $30 \mathrm{~min}$, cooled and transferred to a separating funnel. A total of $30 \mathrm{ml}$ water was used to rinse the flask, the washings being added to the liquid in the funnel. The solution was extracted four times with $25 \mathrm{ml}$ portions of freshly redistilled diethyl ether. The ether extracts were combined and repeatedly washed with $50 \mathrm{ml}$ portions of water, with only gentle shaking at first until the wash water gave no colour with phenolphthalein. The washed ether extract was dried with $5^{-10} \mathrm{~g}$ anhydrous $\mathrm{Na}_{2} \mathrm{SO}_{4}$ and transferred to a $100 \mathrm{ml}$ volumetric flask of low u.v. transmission. The $\mathrm{Na}_{2} \mathrm{SO}_{4}$ was rinsed four times with small portions of ether, the rinsings being added to the main extract, which was then made up to volume. Quantitative removal of vitamin $\mathrm{A}$ from the $\mathrm{Na}_{2} \mathrm{SO}_{4}$ was demonstrated by the absence of colour formation on the addition of a few drops of $\mathrm{SbCl}_{3}$ reagent to the dry residue. 
A measured portion of the ether extract was evaporated to dryness under a stream of nitrogen, in a $\mathrm{I} \circ \mathrm{ml}$ volumetric flask with low u.v. transmission. The residue was immediately dissolved in cyclohexane and made up to volume. The absorbance of the solution was measured at $312.5,326.5$ and $336 \mathrm{~m} \mu$ in a Beckman model DU spectrophotometer. The vitamin A content was calculated by means of a conversion factor of I900 and by applying the correction procedure of Morton \& Stubbs (I948) as elaborated by Morton (I950).

When irrelevant absorption was excessive, a further portion of the ether extract was evaporated and the residue taken up in chloroform for the determination of the vitamin A content with the Carr-Price reagent by the method of Cama, Collins \& Morton (I95I).

\section{RESULTS}

Mean and median values. Of the II I samples of liver analysed, forty-seven were obtained during $195 \mathrm{I}$ and sixty-four in $1960-\mathrm{I}$. As the results for these two groups were similar, they have been treated as a single group for the purposes of this paper. Although the total number is not large, we are reporting the results because there is no immediate prospect of extending the series. The age of the subjects ranged from o (stillborn) to 85 years. The range of distribution of vitamin A concentrations in the livers of seventy-five subjects over ro years of age is shown in Fig. I.

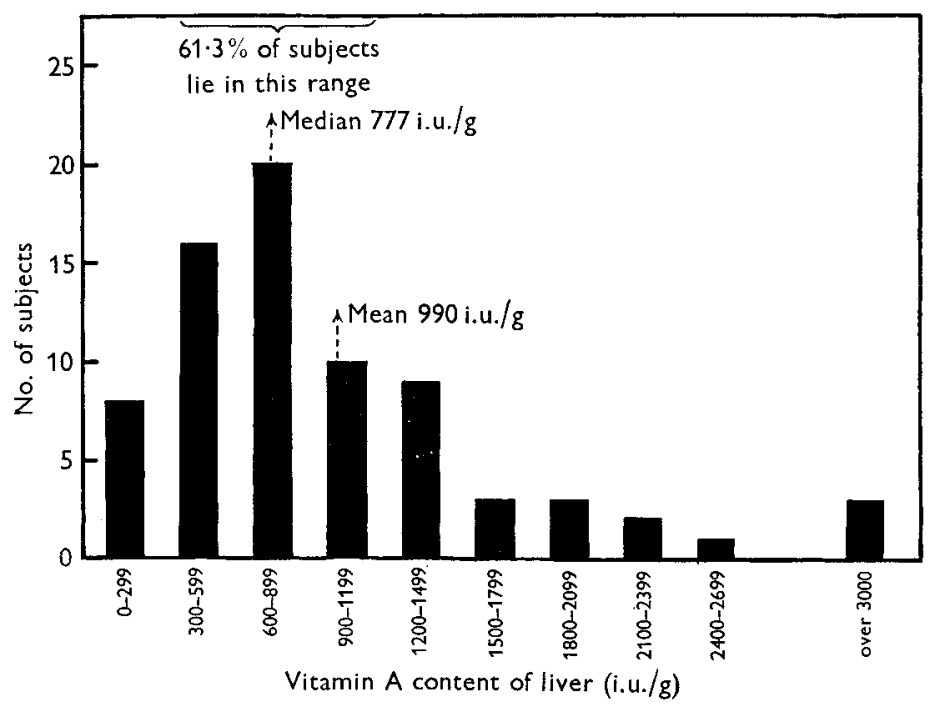

Fig. I. Vitamin A concentration in the livers of seventy-five New Zealand subjects over Io years of age.

The exceptionally high value for a young adult of ro $438 \mathrm{i} . \mathrm{u} . / \mathrm{g}$, associated with an unusually high daily prescription of vitamin A, was not included in the general series, being considered atypical.

In thirty-nine children dying under Io years of age the mean was $10_{4} \mathrm{I} \cdot 4 \mathrm{i} . \mathrm{u} . / \mathrm{g}$, the median being $353 \mathrm{i} . \mathrm{u} . \mathrm{g}$. In these subjects $60 \%$ were closely grouped in the range o-500 i.u./g. Here also were some unusually high values, e.g. 4720 and $6878 \mathrm{i.u} . / \mathrm{g}$. 
The mean for samples from 1 IO adults and children was 1006 i.u./g, the median being 757 i.u./g.

Vitamin $A$ in relation to age. The findings for successive age periods are arranged in Table $\mathrm{I}$.

The table demonstrates that there was a lower median value for infants under I year of age than for those in other age groups. Children from I to ro years had markedly higher liver stores (with a median value of 1982 i.u./g) than other groups; among adults the range was wide, with little variation between age groups.

Vitamin A in relation to disease. The subjects were divided into groups according to primary cause of death. This type of classification has many limitations but certain information may be obtained from the figures summarized in Table 2.

Table I. Vitamin A concentration in human liver in relation to age in New Zealand

$\begin{array}{cc}\begin{array}{c}\text { Age } \\ \text { (years) }\end{array} & \begin{array}{c}\text { No. of } \\ \text { subjects }\end{array} \\ \text { I } & 23 \\ \text { I-IO } & \text { I2 } \\ \text { I I-20 } & 5 \\ 2 \text { I-40 } & \text { II } \\ 4 I-50 & \text { I I } \\ 5 x-60 & \text { I } 4 \\ 6 \text { I-70 } & \text { I7 } \\ \text { 7I and over } & \text { I7 }\end{array}$

\begin{tabular}{rrr}
\multicolumn{2}{c}{ Vitamin A (i.u./g liver) } \\
\multicolumn{1}{c}{ Range } & Mean & Median \\
o-1633 & 327 & 163 \\
$427-6868$ & 2409 & 1982 \\
$298-1396$ & 928 & 857 \\
$35-1926$ & 961 & 836 \\
$309-2475$ & 1036 & 755 \\
$325-3313$ & 1253 & 843 \\
$16-1534$ & 661 & 658 \\
$117-3260$ & 1107 & 891
\end{tabular}

Table 2. Vitamin A concentration in human liver in relation to disease in New Zealand

\begin{tabular}{|c|c|c|c|c|}
\hline \multirow[b]{2}{*}{ Cause of death } & \multirow[b]{2}{*}{$\begin{array}{l}\text { No. of } \\
\text { subjects }\end{array}$} & \multicolumn{3}{|c|}{ Vitamin A (i.u./g liver) } \\
\hline & & Range & Mean & Median \\
\hline Street or indoor accident & I3 & $323-1895$ & I I IO & 1256 \\
\hline Neonatal death & 15 & $0-446$ & 142 & 102 \\
\hline Stillbirth & 2 & $89-298$ & $\longrightarrow$ & - \\
\hline Acute disease & 22 & $337^{-4720}$ & I399 & 939 \\
\hline $\begin{array}{l}\text { Arteriosclerotic and degenerative } \\
\text { heart disease }\end{array}$ & 14 & $247^{-}-33 \times 3$ & I I I I & 843 \\
\hline Pulmonary embolism & 5 & $634-3150$ & I 412 & I300 \\
\hline Congestive heart failure & 5 & $295^{-2175}$ & I 185 & 760 \\
\hline Congenital heart disease & 4 & $35-1305$ & 628 & 587 \\
\hline Neoplastic disease & 18 & I $90-3237$ & 1058 & 846 \\
\hline Chronic disease & IO & I I $7-1165$ & 592 & 540 \\
\hline
\end{tabular}

There was little variation between groups except among that of fifteen neonatal deaths (up to I I days after birth in this series) in which the level was considerably lower, and much narrower in range, than in other groups. It was, nevertheless, much higher than the mean of 27 i.u./g recorded by Ellison \& Moore (1937) for a group of eleven deaths among children under 4 weeks of age in Britain, or Wolff's (1932) mean of 42 i.u./g for a group of forty-two deaths among newborn Dutch children, of whom eighteen were premature. In the latter series one infant had $24^{\circ} \mathrm{i} . u$. $/ \mathrm{g}$, in the liver. and fourteen had no perceptible vitamin A. 


\section{DISCUSSION}

In Table 3 we include our New Zealand values with those previously recorded in other countries. The New Zealand subjects had a higher mean amount of liver vitamin $A$ than had those studied in other countries. In the accidental-death group, the mean of I I Io i.u./g for the thirteen in the New Zealand series is about $\mathrm{I} \cdot 5$ times the mean for twenty-three reported by Ralli, Papper, Paley \& Bauman (I94r) for the United States of America, about 3.8 times that of Moore's (1937) group of forty and 3.4 times the central liver reserve level of Moore \& Cooper's (I94I-4) seventy-one in the $15-59$ age group in Britain.

Two exceptional cases are not listed in Table 2 : one was a 68-year-old male who died of inanition, with a hepatic content of only 16 i.u./g; the other, an 8-year-old child with a familial renal defect, died from nephrosis after a considerable period in hospital, with a level of $6878 \mathrm{i.u} . \mathrm{g}$.

Table 3. Liver stores of vitamin A previously recorded, compared with those found in this study

\begin{tabular}{|c|c|c|c|c|}
\hline Author & $\begin{array}{c}\text { Vitamin A } \\
\text { (i.u./g liver) }\end{array}$ & $\begin{array}{l}\text { Nationality } \\
\text { of subjects }\end{array}$ & $\begin{array}{l}\text { No. of } \\
\text { subjects }\end{array}$ & Comment \\
\hline Green (1932) & $\begin{array}{r}88 \cdot 9^{*} \\
135^{\cdot 6 *}\end{array}$ & $\begin{array}{l}\text { British } \\
\text { British }\end{array}$ & $\begin{array}{l}7 \\
7\end{array}$ & $\begin{array}{l}\text { Women dying of puerperal sepsis } \\
\text { Non-septic puerperal cases }\end{array}$ \\
\hline Wolff (1932) & $\begin{aligned} 42^{*} \\
161^{*}\end{aligned}$ & $\begin{array}{l}\text { Dutch } \\
\text { Dutch }\end{array}$ & $\begin{array}{l}\text { I } 8 \\
78\end{array}$ & $\begin{array}{l}\text { Newborn or stillborn infants } \\
\text { Accidental deaths }\end{array}$ \\
\hline Fox (1933) & $\begin{array}{r}178 * \\
98 *\end{array}$ & Bantu & I4 & $\begin{array}{l}\text { Accidental deaths among mine } \\
\text { labourers } \\
\text { Labourers dying of pneumonia }\end{array}$ \\
\hline Moore (1937) & 290 & British & 40 & Accidental death in $15^{-59}$ age group \\
\hline $\begin{array}{l}\text { Moore \& Cooper } \\
\left(\mathrm{I} 94^{\mathrm{I}-4)}\right.\end{array}$ & $\begin{array}{l}324 \\
273\end{array}$ & $\begin{array}{l}\text { British } \\
\text { British }\end{array}$ & $\begin{array}{l}71 \\
29\end{array}$ & $\begin{array}{l}\text { Accidental death in under } 15 \text { age } \\
\text { group } \\
\text { Accidental death in } 15-59 \text { age group } \\
\text { Accidental death in over } 60 \text { age group }\end{array}$ \\
\hline Ralli et al. (194r) & 766 & American & 23 & Accidental death \\
\hline $\begin{array}{l}\text { Dzialoszyński \& } \\
\text { Tomaszewski (1947) }\end{array}$ & 586 & Scottish & I I & Accidental death \\
\hline Berger (1954) & 205 & Polish & $I_{4}$ & Accidental death \\
\hline This study & $\begin{array}{l}1110 \\
1006\end{array}$ & $\begin{array}{l}\text { New Zealand } \\
\text { New Zealand }\end{array}$ & $\begin{array}{r}\mathrm{I}_{3} \\
\text { IIO }\end{array}$ & $\begin{array}{l}\text { Accidental death } \\
\text { Death from any cause (o- } 85 \text { age group) }\end{array}$ \\
\hline
\end{tabular}

* Stated in 'blue units'; converted into i.u. on the basis $\mathrm{r}$ blue unit $\equiv 0.6$ i.u. (Moore, 1957).

Because of extraordinary contributing factors, the unusually high finding of Io 438 i.u./g in a $2 \mathrm{I}$-year-old male was excluded from all previous categories. Four months before his death, an unsuccessful attempt at suicide by swallowing caustic soda had caused ulceration of the oesophagus and stomach. A stricture required surgery and tube-feeding, diabetes complicated the situation, and inanition developed. While in hospital this man was prescribed 50000 i.u. vitamin A daily, apart from the vitamin present in the synthetic tube-feed. The pathologist's report stated that the appearance of the liver cells was normal. We do not know to what extent human liver is capable of 
concentrating vitamin $A$, or whether the level attained in this instance was near saturation. In their studies on rats, Davies \& Moore (1935) gave vitamin A to rats until their livers appeared incapable of holding any more; on subsequent examination the levels reached were usually of the order of $10000 \mathrm{i} . \mathrm{u}$./g.

Several factors may contribute to the high concentration of vitamin A found by us in the livers of healthy subjects.

(I) New Zealand's butter consumption per head is the highest recorded in the lists compiled by FAO (1960); the daily mean of $44.7 \mathrm{~g}$ /person shows a big lead over Australia, next on the list with $29.4 \mathrm{~g} /$ person. The habitual generous use of butter arises from its ready availability, the absence of table margarine and a government subsidy of $8 d$. $/ 1 \mathrm{~b}$, which makes the retail price $2 s . / 1 \mathrm{~b}$. There are no quantitative records more recent than those collected in the summer of 1939 by McLaughlin (1943) for the dietaries of basic wage-earners (tramwaymen and boot operatives) and their families, who showed high intakes of vitamin $\mathrm{A}$ and carotene.

(2) Studies in other countries, with which our figures have been compared, were for the most part made before vitamin A became a regular addition there to table margarine and before the use of fish-liver oils became widespread.

(3) Infant welfare services in New Zealand have a wide coverage, the percentage coming under supervision being 88.6 (Consultative Committee on Infant and Preschool Health Services, 1960). Though there is no national scheme for supplying welfare foods, the use of fish-liver oils for infants is begun early and is virtually universal; further, many children are given fish oils as a prophylactic measure in winter-time against rickets and also supposedly to prevent winter colds.

(4) Many adults also yield to the persuasion of advertisements for vitamins and either purchase proprietary mixtures or else take advantage of free pharmaceutical benefits by seeking a prescription from their doctor.

\section{SUMMARY}

I. Determinations of the vitamin A content of liver from I Io autopsies of New Zealand subjects indicated that there were considerable variations but a high median value ( 757 i.u. $/ \mathrm{g}$ ) compared with figures reported from other countries.

2. Children from $I$ to Io years had higher liver stores (median $I 982 \mathrm{i} . u . / \mathrm{g}$ ) than adults, for $6 \mathrm{x} \cdot 3 \%$ of whom the values were within the range $300-\mathrm{I} 199 \mathrm{i.u} / \mathrm{g}$.

3. For fourteen subjects dying from accidents, the median value was I 256 i.u./g.

4. Those undergoing neonatal deaths showed the lowest amounts (median I02 i.u. $/ \mathrm{g}$ ), though these were higher than those generally reported for other countries.

5. The findings are ascribed to a liberal intake of butter, a dietary with ample vitarmin $\mathrm{A}$ and carotene, and the wide use of medicinal preparations containing or made from fish-liver oils, particularly for infants and children.

We are grateful to the following pathologists and their technical assistants for their kind co-operation in sending weighed samples of liver:

Professor E. D'Ath and the staff of the Pathology Department, Medical School, 
Dunedin; Dr R. Lycett, Hawkes Bay Hospital Board, Hastings; Dr J. O. Mercer, Wellington Public Hospital; Dr N. Prentice, Invercargill Public Hospital; Dr Pullar, Palmerston North Public Hospital; Dr Flora Smith, Auckland Public Hospital; and Dr D. Stewart, Christchurch Public Hospital.

We thank also Dr Muriel Bell for her kind co-operation and encouragement.

\section{REFERENCES}

Berger, S. (1954). Roczn. Zakl. Hig., Warsz., 5, 207.

Cama, H. R., Collins, F. D. \& Morton, R. A. (I95 I). Biochem. F. 50, 48.

Consultative Committee on Infant and Pre-school Health Services. (r960). (Chairman: Sir George Finlay). Report. Wellington, New Zealand: Government Printer.

Davies, A. W. \& Moore, T. (1935). Biochem. F. 29, I47.

Dzialoszyński, L. \& Tomaszewski, W. (1947). Edinb. med. F. 54, 25 I.

Ellison, J. B. \& Moore, T. (1937). Biochem. F. 3r, x65.

FAO (1960). Food Supply, Time Series.

Fox, F. W. (I933). Lancet, 224, 953.

Green, H. N. (1932). Lancet, 223, 723.

Hume, E. M. \& Krebs, H. A. (1949). Spec. Rep. Ser. med. Res. Coun., Lond., no. 264.

Kerppola, W. (1930). Skand. Arch. Physiol. 56, г8 г.

McLaughlin, E. C. G. (1943). New Zealand med. F. 42, I 55.

Moore, T. (I93 I). Biochem. F. 25, 275.

Moore, T. (1937). Biochem. F. 31, I55.

Moore, T. (1957). Vitamin A, p. 564. Amsterdam: Elsevier Publishing Co.

Moore, T. \& Cooper, A. C. (1941-4). Quoted by Hume \& Krebs (1949).

Morton, R. A. (1950). F. Pharm., Lond., 2, 129.

Morton, R. A. \& Stubbs, A. L. (1948). Biochem. F. 42, I 95.

Ralli, E. P., Papper, E., Paley, K. \& Bauman, E. (194I). Arch. intern. Med. 68, ro2.

Sherman, H. C. \& Boynton, L. C. (1925). F. Amer. chem. Soc. 47, 1646.

U.S. Pharmacopoeia, XIV (1950), p. 784 .

Wolff, L. K. (1932). Lancet, 223, 6I7. 